\title{
Selection of novel peptide mimics of the GD2 ganglioside from a constrained phage-displayed peptide library
}

\author{
IRENA HORWACIK ${ }^{1}$, DOMINIK CZAPLICKI ${ }^{1}$, KATARZYNA TALAREK $^{1}$, ALEKSANDRA KOWALCZYK $^{1}$, \\ ELZBIETA BOLESTA ${ }^{2}$, DANUTA KOZBOR ${ }^{2}$ and HANNA ROKITA ${ }^{1}$ \\ ${ }^{1}$ Faculty of Biochemistry, Biophysics and Biotechnology, The Jagiellonian University, 7 Gronostajowa St., \\ 30-387 Krakow, Poland; ${ }^{2}$ Department of Immunology, Roswell Park Cancer Institute, \\ Elm and Carlton Streets, Buffalo, NY 14263, USA
}

Received November 20, 2006; Accepted December 27, 2006

\begin{abstract}
Aberrant glycosylation is a universal feature of cancer cells. There are quantitative and qualitative changes in expression of gangliosides observed in tumors of a neuroectodermal origin such as neuroblastoma, melanoma and astrocytoma. The presence of large amounts of GD2 ganglioside on neuroblastoma cells, as compared to normal cells, opens the possibilities to use the tumor-associated carbohydrate antigen in diagnosis and immunotherapeutic approaches. In the quest for immunogens potentially capable of eliciting anti-GD2 ganglioside immune responses, we performed affinity purification of phage-displayed peptides from the LX-8 library (12-mer containing disulphide bridge). The library was screened with the biotinylated anti-GD2 ganglioside 14G2a mAb monoclonal antibody. Our goal was to isolate and characterize peptide mimics of GD2 ganglioside. Numerous individual phage clones that bound $14 \mathrm{G} 2 \mathrm{a}$ mAb were identified with the application of immunoblotting technique in the phage pools yielded from the pannings. The phage-borne peptides were tested for their anti-GD2 ganglioside antibody binding ability using ELISA. Among these clones five different phage-displayed peptide sequences were identified. Moreover, we showed that the secondary structure of the peptides, stabilized by the disulfide bridging between cysteine residues at positions 2 and 11, was crucial for the binding of the peptides to $14 \mathrm{G} 2 \mathrm{a}$ mAb. In a separate set of experiments, we observed a competition of the peptides, expressed on phages as well as in their synthetic form, with the nominal antigen GD2 ganglioside expressed on IMR-32 neuroblastoma cells for binding to $14 \mathrm{G} 2 \mathrm{a}$ mAb. Based on the obtained results we concluded that all of these 5 peptides were mimics of the GD2 ganglioside.
\end{abstract}

Correspondence to: Dr Irena Horwacik, Faculty of Biochemistry, Biophysics and Biotechnology, The Jagiellonian University, 7 Gronostajowa St., 30-387 Krakow, Poland

E-mail: irena@awe.mol.uj.edu.pl

Key words: GD2 ganglioside, 14G2a mAb, phage-displayed peptide library, peptide mimics

\section{Introduction}

GD2 ganglioside belongs to a group of sialylated glycosphingolipids. The molecule has an amphipatic character and consists of an outer charged glycan portion with two sialic acid residues and a ceramide unit, fatty acyl sphingosine. Due to its hydrophobic nature, the sphingolipid tail embeds the molecule in the outer leaflet of the plasma membrane. Changes in ganglioside content (e.g. presence of $O$-acetylated terminal sialic acid residues at the position 7 or 9 of the glycan part, ceramide modifications) are a hallmark of certain types of tumors (1). Due to incomplete synthesis, precursors such as GM2, GM3, GD3 and GD2 gangliosides are accumulated in neuroblastoma, melanoma, small cell lung carcinoma, sarcoma, or B cell lymphoma (2). With reference to a vast number of research data, gangliosides have been related to tumorigenesis (3). An alteration in the ganglioside expression pattern has been linked to biological phenotype and clinical behavior that can be used to predict the prognosis of neuroblastoma patients $(4,5)$. As for the GD2 ganglioside, high circulating levels of the tumor carbohydrate antigen were strongly related to more rapid disease progression and lower survival rates of advanced risk neuroblastoma patients (6). Additional experimental data from culture systems suggest that GD2 may be one of the modulating factors in tumor-host interactions. In particular, SH-SY-5Y neuroblastoma cells stably transfected with a construct encoding cDNA of GD3 synthase exhibited increased levels of both GD2 and GD3 gangliosides. This was accompanied by morphological changes and the tendency to form aggregates of the cells in cultures (7). Yoshida and colleagues showed that in the case of small cell lung cancer cells SK-LC-17, the observed rise in GD2 and GD3 ganglioside content led to an increase in proliferation and invasiveness. Moreover, the anti-GD2 monoclonal antibodies (220-51) were capable of diminishing the proliferation rates of the tumor cell line, in a mechanism that was shown to involve apoptosis. This indirect evidence indicates that the GD2 ganglioside may be involved in tumorigenesis (8). Another widely described phenomenon that may be added to the biological functions of gangliosides is suppression of immune cells by intact ganglioside molecules present on the tumor cells or shed into their microenvironment (9). 
Many anti-GD2 ganglioside monoclonal antibodies have been identified (10). Overexpression of GD2 ganglioside distinguishes neuroblastoma from benign neural tumors (11), which has resulted in the application of antibodies targeting the carbohydrate in the diagnosis of localized and metastatic neuroblastoma and in the monitoring of therapy response and minimal residual disease $(12,13)$. The fact that approximately $60 \%$ of children with neuroblastoma, which is the most common extracranial neoplasm of childhood, have high-risk tumors that can rarely be cured by conventional therapy, stresses the need for new treatment protocols to control minimal residual disease. As GD2 ganglioside is expressed strongly and quite uniformly on neuroblastoma cells and exhibits a restricted localization pattern in normal tissues, the tumor-associated carbohydrate antigen represents a good therapeutical target. Furthermore, GD2 ganglioside is not downregulated when bound by specific antibodies (14). Among the anti-GD2 ganglioside monoclonal antibodies available, two mouse antibodies 3F8 (IgG3), 14G2a (IgG2a) and one chimeric ch14.18 antibody were tested in clinical trials for their anti-tumor activity against neuroblastoma (15). Additionally, the etiology and immunogenicity of neuroblastoma encourage development of active immunotherapies. However, if such therapies are to be successful, they have to overcome self-tolerance to GD2 ganglioside and poor immunogenicity of the antigen in humans. Unlike peptides, most carbohydrates (due to their chemical nature) are thymusindependent antigens. They are not presented in the context of MHC molecules, stimulate primary B-cell responses, and do not require $\mathrm{T}$ cell help. They mainly induce short-lived IgM antibodies (10). Moreover, carbohydrate antigens are difficult and expensive to synthesize because of chirality and low chemical yield. Currently, clinically tested strategies to improve GD2 ganglioside immunogenicity include application of its conjugates with KLH (keyhole limpet hemocyanin) protein carrier and vaccination with substitute immunogens in the form of anti-idiotypic antibodies (in various adjuvant settings) (16).

Another strategy that relies on surrogate antigens of GD2 gangliosides is the application of mimicking peptides, which can be isolated from phage-displayed peptide libraries. The filamentous bacteriophages infecting $E$. coli, of which M13, f1 and fd have been the most extensively studied, are a group of viruses that contain a circular single-stranded DNA genome encased in a long protein capsid. The filamentous phage structure and its mode of replication have made it a valuable tool for biological research. Due to the membraneassociated assembly process of the viruses, it is possible to display foreign peptides and even proteins on the surface of the phage particles, while the genetic material encoding each variant resides inside it. Therefore, by using a receptor, one can apply various in vitro selection techniques to purify binding phage clones from such libraries and analyze their interactions with the screening molecule. The phage display technique has numerous modifications and has been broadly applied, for example, in the production of recombinant antibodies, in the analysis of the interactions among proteins and their domains, in epitope mapping, and in binding motif and small ligand identification (17). One type of such libraries are peptide libraries, where short peptide sequences; random, linear, constrained or even expressed as a fragment of a larger protein scaffold; are expressed as fusion products on the surface of the virions. In many cases, where an antibody was used in screening, the isolated peptides were shown to interact with the antigen-binding site of antibodies recognizing native antigens in the form of proteins, carbohydrates, or nucleic acids. In addition, such peptides compete with the native antigen for binding to the antigen-binding site and therefore are named as their mimics $(18,19)$. Mimetic peptides have been successfully tested in animal models and induce immune responses to carbohydrate compounds present on pathogens and tumor cells $(20,21)$.

In the quest for antigens potentially capable of eliciting anti-GD2 ganglioside immune responses, we performed affinity purification of phage-displayed peptides from the LX-8 library (12-mer containing disulphide bridge) with biotinylated anti-GD2 ganglioside 14G2a mAb. We isolated and characterized five peptide mimics of GD2 ganglioside. We showed that the spatial structure of the isolated phagedisplayed peptides was essential for their mimicking potential. We observed competition of the mimicking peptides with GD2 ganglioside, expressed on IMR-32 neuroblastoma cells, for the antigen-binding site of $14 \mathrm{G} 2 \mathrm{a}$ $\mathrm{mAb}$.

\section{Materials and methods}

Materials. The LX-8 phage-displayed peptide library was produced in the vector $\mathrm{f} 88 \mathrm{-}-4$, as a fd-tet derivative (Entrez Nucleotide accession no. AF218363). The library encoded 12 amino acid (aa) peptides fused to the N-terminus of the major coat protein pVIII. There were 2 fixed Cys residues (C) introduced in the 2 nd and the 11th position of the encoded peptides $\left(\mathrm{XCX}_{8} \mathrm{CX}\right.$, random amino acids (aa) are marked as $X)$. The peptides were followed by AAEGDD (22). The diversity of the library was $1.5 \times 10^{9}$ phage clones. K91Kan (K91) E. coli strain was the bacterial host for filamentous phages in this study. Its sex is Hfr Cavalli, and therefore deploys the F pillus, the attachment site for filamentous phage infection. The mini-kan hopper element was inserted in the lacZ gene using the vector $\lambda$ NK 1105 that confers kanamycin resistance on the cells (23). The hybridoma cell line secreting the mouse monoclonal antibody $14 \mathrm{G} 2$ a was provided by Dr R. A. Reisfeld (The Scripps Institute, La Jolla, CA, USA). The antibody is of the $\mathrm{IgG} 2 \mathrm{a}$ isotype, and binds to GD2 ganglioside (24). For all experiments, the antibody was purified from cell culture media using HI TRAP protein $G$ columns according to the manufacturer's protocol (Amersham Biosciences AB, Uppsala, Sweden). The biotinylation of 14G2a mAb was performed using sulfo-NHS-LC biotin (Sigma, St. Louis, MO, USA) according to the protocol described in (25). Panning experiments and ELISAs were performed in 96-well microplates (MaxiSorp, NUNC A/S, Roskilde, Denmark). A horseradish peroxidase (HRP)conjugated, anti-pVIII monoclonal antibody, developed in the mouse, was obtained from Amersham Biosciences. HRPconjugated anti-mouse Ig polyclonal antibodies, developed in the rabbit, were purchased from Sigma. FITC-conjugated $\mathrm{F}\left(\mathrm{ab}^{\prime}\right)_{2}$ fragments raised against murine $\operatorname{IgG}$, IgM and $\operatorname{IgA}$, developed in the goat, were from MP Biomedicals, Inc. 
(Aurora, $\mathrm{OH}, \mathrm{USA})$. A human neuroblastoma cell line IMR32 (CCL-127, ATCC) (26), expressing high levels of GD2 ganglioside (27), was cultured using E-MEM; $1 \mathrm{mM}$ sodium pyruvate, $1 \%$ non-essential amino acid solution (all from Sigma), $10 \%$ FBS, $100 \mu \mathrm{g} / \mathrm{ml}$ penicillin, $0.25 \mu \mathrm{g} / \mathrm{ml}$ streptomycin and $0.085 \%$ amphotericine B (Invitrogen Ltd., Paisley, UK) at $37^{\circ} \mathrm{C}$ in a humidified $5 \% \mathrm{CO}_{2}$ incubator. Synthetic peptides were from Sigma Genosys (The Woodlands, TX, USA). All other chemicals were purchased form Sigma unless stated otherwise.

Screening of the LX-8 library with $14 G 2 a m A b$. The major steps describing the panning experiments are described below. Phage clones binding to $14 \mathrm{G} 2 \mathrm{a}$ mAb were isolated during 4 rounds of an 'in-solution' panning (phage clones \#8, \#65, \#85 and \#94) and 6 rounds of a 'solid' phase panning (a phage clone \#D). For both types of pannings, in their first rounds $1 \times 10^{13}$ phage particles $(\mathrm{ph})\left(6.7 \times 10^{3}\right.$ equivalents of the library) per well were screened. To remove nonspecific binders, the library, diluted in TBS containing 2\% BSA and 0.5\% Tween-20 [TBS: $50 \mathrm{mM}$ Tris- $\mathrm{HCl}, \mathrm{pH} 7.5,150 \mathrm{mM}$ $\mathrm{NaCl}$ and bovine serum albumin (BSA) (Amresco Inc. Solon, $\mathrm{OH}, \mathrm{USA}$ )] was preadsorbed for $4 \mathrm{~h}$ at room temperature (RT) in wells previously coated with streptavidin (SA, $1 \mu \mathrm{g}$ per well in TBS), blocked with $2 \%$ BSA in TBS, and then washed 3 times with $0.5 \%$ Tween-20 in TBS.

During the 'in solution' panning the non-adsorbed phages were removed and incubated with the biotinylated 14G2a $\mathrm{mAb}$ at 1-, 3-, 10- and 30-nM concentrations overnight $(\mathrm{O} / \mathrm{N})$ at $4^{\circ} \mathrm{C}$. Phage-antibody complexes were isolated on the SAcoated, BSA-blocked microplates for $15 \mathrm{~min}$ at RT with rocking. The reaction was stopped by the addition of TBS containing 10 nmoles of biotin and $2 \% \mathrm{BSA}$, for the last $5 \mathrm{~min}$ of incubation. Non-bound phages were removed during 6 washes with TBS containing $0.5 \%$ Tween-20. LB (30 $\mu 1)$ was added to each well, and infection of the binders with $\sim 5 \times 10^{7}$ cells of starved K91 in $10 \mu 1$ of NAP buffer $(80 \mathrm{mM}$ $\mathrm{NaCl}$ and $50 \mathrm{mM} \mathrm{NH} \mathrm{H}_{2} \mathrm{PO}_{4}, \mathrm{pH}$ 7.0) was carried out for $15 \mathrm{~min}$ at RT. Then, the tetracycline resistance genes were induced by the addition of tetracycline (tet) in LB to a final concentration of $0.2 \mu \mathrm{g} / \mathrm{ml}$ with shaking $\left(45 \mathrm{~min}, 37^{\circ} \mathrm{C}\right.$, $100 \mathrm{rpm})$. In the next step, the antibiotic concentration was increased to a bacteriostatic level $(15 \mu \mathrm{g} / \mathrm{ml})$, while simultaneously the tac promoter, controlling the expression of the recombinant gene VIII, was induced by the addition of IPTG to a final concentration of $1 \mathrm{mM}$ (Amresco). The amplification step was carried out with gentle shaking in a humidified container $\left(42 \mathrm{~h}, 37^{\circ} \mathrm{C}\right)$. To collect the amplified phages, media were transferred to $1.5-\mathrm{ml}$ Eppendorf tubes and centrifuged for $1 \mathrm{~h}$ at $1500 \mathrm{xg}$ at $4^{\circ} \mathrm{C}$. Supernatants were transferred to fresh tubes. The remaining bacteria were heatkilled $\left(20 \mathrm{~min}, 70^{\circ} \mathrm{C}\right)$, and then removed by centrifugation (as above). The second, third and fourth rounds of panning were performed with the following modification; $40 \mu 1$ of medium with amplified phages was used in these rounds of panning, and the incubation time of phage-antibody complexes in the SA-coated wells was decreased to $10 \mathrm{~min}$. During the fourth round of panning, to increase the possibility of finding highbinding clones, the concentration of the biotinylated 14G2a $\mathrm{mAb}$ was decreased. The phage pools incubated in the preceding rounds with 10- and 30-nM antibody concentrations were panned using 14G2a mAb at 1- and 3-nM concentrations.

The 'solid phase' panning was performed as described above with the following modifications; the SA-coated, BSA-blocked wells were saturated with $35 \mu 1$ of $100 \mathrm{nM}$ biotinylated 14G2a mAb (20 min, RT). The remaining SA sites were blocked with 10 nmoles of biotin ( $5 \mathrm{~min}, \mathrm{RT}$ ). Then, the wells were washed with TBS containing $0.5 \%$ Tween-20 (3 times), and the preadsorbed library was incubated in the wells $(2 \mathrm{~h}, \mathrm{RT})$ with rocking. Prior to the infection of the K91 cells, the phages were eluted with $35 \mu \mathrm{l}$ of a buffer containing $0.1 \mathrm{M} \mathrm{HCl}$ (pH 2.2 with glycine), $0.1 \%$ BSA (10 min, RT), and then neutralized with $7 \mu \mathrm{l}$ of $1 \mathrm{M}$ Tris-HCl (pH 9.0).

For both types of screening experiments, after each round, titering was performed to determine the efficiency of infection and percentage yield of the bound phages. The amplification yield was determined with agarose gel electrophoresis of the viral ssDNA. ELISAs were performed to estimate the enrichment of 14G2a binding clones in the amplified phage pools (28).

Immunoblotting. The first series of immunoblotting experiments was performed to isolate the 14G2a binding phage clones after the panning experiments. Phage particles $\left(10^{5}\right)$ in TBS containing $0.1 \%$ gelatin (from pools amplified during the last rounds of the pannings) were used to infect K91 cells $\left(\sim 10^{9}\right.$ cells in $\left.\mathrm{LB}\right)$ for $10 \mathrm{~min}$ at $\mathrm{RT}$. After infection and tetracycline resistance gene induction (as above), bacteria were grown in the presence of $20 \mu \mathrm{g} / \mathrm{ml}$ tet $(1 \mathrm{~h}, 250 \mathrm{rpm}$, $37^{\circ} \mathrm{C}$ ), and then titered. In the next step, $\sim 200$ bacterial colonies were grown on NZY/agar plates with $100 \mu \mathrm{g} / \mathrm{ml}$ kanamycin $(\mathrm{kan})$ and $20 \mu \mathrm{g} / \mathrm{ml}$ tet $\left(\mathrm{O} / \mathrm{N}, 37^{\circ} \mathrm{C}\right)$. Replicas of the bacteria were prepared on nitrocellulose membranes (Schleicher and Schuller BioScience Inc., Dassel, Germany). The membranes with the transferred bacterial colonies were washed 3 times in TNT buffer (10 mM Tris- $\mathrm{HCl}, \mathrm{pH} 7.5$, $150 \mathrm{mM} \mathrm{NaCl}$ and $0.05 \%$ Tween-20), and then blocked with TNT containing 5\% non-fat dry milk (Gostynin, Poland) with rocking ( $1 \mathrm{~h}, \mathrm{RT})$. Then, the membranes were incubated with $2 \mu \mathrm{g} / \mathrm{ml}$ of the $14 \mathrm{G} 2 \mathrm{a}$ mAb dissolved in TNT containing $1 \%$ BSA $\left(\mathrm{O} / \mathrm{N}, 4^{\circ} \mathrm{C}\right)$. The membranes were washed 3 times with TNT containing $0.1 \% \mathrm{BSA}$ and incubated with the antimouse Ig antibodies, diluted 1:15,000 in TNT containing 1\% BSA (1 h, RT, with rocking). After 3 washings (as above), the signal was developed with ECL Plus Western blot detection reagent (Amersham BioSciences, San Diego, CA, USA). Finally, the membranes were exposed to film (CEA AB, Strängnäs, Sweden), and developed (Foma, Bohemia Ltd, Hradec Králové, Czech Republic). Selected bacterial colonies with phages binding to $14 \mathrm{G} 2 \mathrm{a} \mathrm{mAb}$ were grown in $2 \mathrm{ml}$ of LB with $100 \mu \mathrm{g} / \mathrm{ml} \mathrm{kan}$ and $20 \mu \mathrm{g} / \mathrm{ml}$ tet $\left(4 \mathrm{~h}, 37^{\circ} \mathrm{C}\right)$ with shaking $(250 \mathrm{rpm})$. The phage amplification yield was estimated by gel electrophoresis and titering. The second round of immunoblotting experiments was performed on the amplified phage clones to confirm their binding to $14 \mathrm{G} 2 \mathrm{a}$ mAb.

Purification of phage particles by polyethylene glycol precipitation. Prior to ELISAs, sequencing and competition tests, phage clones were amplified and purified by double precipitation with polyethylene glycol (PEG). A small-scale 
amplification of a single phage-infected bacterial colony was carried out in $2.5 \mathrm{ml}$ of LB containing $15 \mu \mathrm{g} / \mathrm{ml}$ tet $(\mathrm{O} / \mathrm{N}$, $37^{\circ} \mathrm{C}$, with shaking for $250 \mathrm{rpm}$ ). The next day, the media were centrifuged $\left(20 \mathrm{~min}, 4^{\circ} \mathrm{C}, 1300 \mathrm{x} \mathrm{g}\right)$. Phages were precipitated twice by the addition of a 0.15 volume of $\mathrm{PEG} / \mathrm{NaCl}$ solution (16.7\% polyethylene glycol-8000; $3.3 \mathrm{M}$ $\mathrm{NaCl}$ ) to the supernatants, followed by thorough mixing and incubation on ice $(4 \mathrm{~h}$ for the first incubation, $\mathrm{O} / \mathrm{N}$ for the second incubation). For both precipitations phage particles were recovered by centrifugation $\left(40 \mathrm{~min}, 4^{\circ} \mathrm{C}, 10,000 \mathrm{x} \mathrm{g}\right)$, pellets were dissolved in TBS followed by incubation on ice $(1 \mathrm{~h})$, and the non-dissolved material was discarded after the final centrifugation $\left(1 \mathrm{~min}, 4^{\circ} \mathrm{C}, 16,100 \mathrm{x} \mathrm{g}\right)$.

For large scale amplification of selected phage clones, $10^{8} \mathrm{ph}$ in $1 \mathrm{ml}$ of $0.1 \%$ gelatin/TBS were mixed with an equal volume of K91 cells $\left(5 \times 10^{9}\right)$ in a $50-\mathrm{ml}$ tube $(10 \mathrm{~min}, \mathrm{RT})$. The tetracycline resistance genes were induced (as above), and the samples were incubated with shaking $\left(30 \mathrm{~min}, 37^{\circ} \mathrm{C}\right.$, $250 \mathrm{rpm})$. Then the tet concentration was increased to $20 \mu \mathrm{g} /$ $\mathrm{ml}$, and the incubation was continued $(\mathrm{O} / \mathrm{N})$. On the following day, the media were centrifuged $\left(10 \mathrm{~min}, 4^{\circ} \mathrm{C}\right.$, $6,200 \mathrm{x}$ ), and $\mathrm{PEG} / \mathrm{NaCl}$ was added (0.15 volume), followed by thorough mixing and an incubation step $(\mathrm{O} / \mathrm{N}$, $4^{\circ} \mathrm{C}$ ). To recover the precipitated phage particles, the samples were centrifuged for $40 \mathrm{~min}$ at $4^{\circ} \mathrm{C}$ at $6,200 \mathrm{x} \mathrm{g}$. The phage pellets were dissolved in $1 \mathrm{ml}$ of TBS, and incubated (30 min, $37^{\circ} \mathrm{C}$ ) with gentle shaking. Then, the samples were transferred to 2-ml tubes, and the non-dissolved material was removed by centrifugation $\left(10 \mathrm{~min}, 4^{\circ} \mathrm{C}, 14,500 \mathrm{x} \mathrm{g}\right)$. Again, the supernatants were transferred to fresh tubes, and the second phage precipitation was performed on ice $(3 \mathrm{~h})$, followed by centrifugation $\left(15 \mathrm{~min}, 4^{\circ} \mathrm{C}, 16,100 \mathrm{x} \mathrm{g}\right)$. The viral pellets were dissolved in $1 \mathrm{ml}$ of TBS, and then incubated on ice ( $1 \mathrm{~h})$. Finally, the non-dissolved material was removed by centrifugation $\left(10 \mathrm{~min}, 4^{\circ} \mathrm{C}, 16,100 \mathrm{x} \mathrm{g}\right)$, and the supernatants were transferred to fresh tubes.

The phage concentrations were measured by scanning diluted samples from 240 to $320 \mathrm{~nm}$ using a UV spectrophotometer (Pharmacia BioSciences Biochrom Ltd., Cambridge, UK) and gel electrophoresis along with samples of known concentrations.

ELISAs. Microplate wells were coated with $1 \mu \mathrm{g}$ per well of $\mathrm{SA}$ in TBS $\left(\mathrm{O} / \mathrm{N}, 4^{\circ} \mathrm{C}\right)$, blocked with TBS containing $2 \%$ BSA $\left(30 \mathrm{~min}, 37^{\circ} \mathrm{C}\right.$ ), and then washed 3 times with TBS containing $0.5 \%$ Tween-20. The biotinylated $14 \mathrm{G} 2 \mathrm{a}$ mAb (0.04 $\mu \mathrm{g}$ in TBS containing 2\% BSA and 0.5\% Tween-20) was added to each well, followed by incubation with rocking ( $1 \mathrm{~h}, \mathrm{RT})$. Then, the wells were washed (6 times with TBS containing $0.5 \%$ Tween-20). Phage samples, i.e. media from pannings or amplified phage clones in TBS containing $2 \%$ BSA and $0.5 \%$ Tween-20 were incubated with rocking $(1 \mathrm{~h}$, RT). In the next step, the wells were washed again (as above). Bound phages were detected with $35 \mu 1$ of the anti-pVIII mAb diluted $1: 4,000$ in TBS containing $2 \%$ BSA and $0.5 \%$ Tween-20 (1 h, RT), followed by another washing step. The signal was developed with a TMB substrate (BD BioSciences Pharmingen, San Diego, CA, USA), and read with a spectrophotometer at $450 \mathrm{~nm}$ (Molecular Devices, Sunnyvale, CA, USA). Each determination was performed in duplicate.
Phage ELISAs under reducing conditions were performed to determine the role in the peptide binding played by the disulfide bridging between peptidic cysteine residues in the positions 2 and 11 . The phage clones representing 5 different peptide sequences (phage \#8, \#85, \#94, \#65 and \#D) and a phage \#0 (a phage clone which did not bind to the $14 \mathrm{G} 2 \mathrm{a}$ $\mathrm{mAb}$ in the immunoblotting experiments) were dissolved in TBS, and immobilized in microplates $\left(\mathrm{O} / \mathrm{N}, 4^{\circ} \mathrm{C}\right)$. The next day, the non-bound phages were removed, and the wells were blocked with $\mathrm{TBS}$ containing $2 \% \mathrm{BSA}\left(30 \mathrm{~min}, 37^{\circ} \mathrm{C}\right)$. Then, the wells were washed 3 times with TBS containing $0.5 \%$ Tween-20. Modification of the peptide disulphide bonds was introduced in two steps (both performed for $30 \mathrm{~min}$ at $4^{\circ} \mathrm{C}$ ). In the first step, the appropriate wells were subjected to reducing conditions through the addition of $35 \mu 1$ of $100 \mathrm{mM}$ dithiothreitol in TBS $\left(\mathrm{DTT}^{+} / \mathrm{NEM}^{-}, \mathrm{DDT}^{+} / \mathrm{NEM}^{+}\right)$. In the second step, cysteine-blocking was introduced through the addition of $35 \mu \mathrm{l}$ of $100 \mathrm{mM} \mathrm{N}$-ethylmaleimide in TBS $\left(\mathrm{DTT}^{-} / \mathrm{NEM}^{+}\right)$or $35 \mu \mathrm{l}$ of $15 \mathrm{mM}$ DTT, $100 \mathrm{mM}$ NEM in TBS $\left(\mathrm{DDT}^{+} / \mathrm{NEM}^{+}\right)$. Controls were used including phage clones treated with $35 \mu 1$ of TBS (DDT-/ $\mathrm{NEM}^{-}$), BSA conjugate of non-constrained \#47 peptide (29) or BSA alone. Then, the contents of the wells were removed, and $35 \mu \mathrm{l}$ of the $14 \mathrm{G} 2 \mathrm{a} \mathrm{mAb}(1 \mu \mathrm{g} / \mathrm{ml})$ in TBS containing $5 \mathrm{mM}$ DTT, $2 \% \mathrm{BSA}$ and $0.1 \%$ Tween-20 was added to the $\mathrm{DTT}^{+} / \mathrm{NEM}^{-}$ and $\mathrm{DTT}^{+} / \mathrm{NEM}^{+}$wells, while the mAb solution without DTT was applied to the DDT-/NEM- and DDT-/NEM ${ }^{+}$wells. Following $1 \mathrm{~h}$ of incubation (RT, with rocking), and a washing step (6 times with TBS containing $0.5 \%$ Tween-20), the HRP-conjugated anti-mouse Ig antibodies were used to detect the bound $14 \mathrm{G} 2 \mathrm{a} \mathrm{mAb}\left(1 \mathrm{~h}, 37^{\circ} \mathrm{C}\right)$. The secondary antibodies were diluted 1:4,000 in TBS containing 2\% BSA and $0.1 \%$ Tween-20. After the final washing step (as above), the signal was developed with the TMB substrate, and read with a spectrophotometer at $450 \mathrm{~nm}$. Each determination was performed in duplicate.

Sequencing. The phage clones were sequenced using the primer 5' GCCAATAGTAGCACCAACGATA 3' (DNA Sequencing and Oligonucleotide Synthesis Facility, Institute of Biochemistry and Biophysics, Polish Academy of Science, Warsaw, Poland), and the sequences of the peptide coding region of the recombinant fusion $p$ VIII gene protein were analyzed using Chromas (version 1.45). Peptide sequence analysis was performed with ClustalW, a command line interface of Clustal. Clustal is a general purpose multiple sequence alignment program for DNA and proteins. An amino acid identity matrix was used to generate the alignment and a branching diagram for the five isolated peptide sequences (30).

Competition tests. Phage particles $\left(10^{12}\right)$ of the clones expressing the 5 different peptides (and the phage \#0) were diluted in PBS containing 2\% BSA, and then incubated with $200 \mathrm{ng}$ of $14 \mathrm{G} 2 \mathrm{a} \mathrm{mAb}\left(\mathrm{O} / \mathrm{N}, 4^{\circ} \mathrm{C}\right)$. The next day the samples were mixed with $1 \times 10^{5}$ IMR-32 neuroblastoma cells and incubated for $45 \mathrm{~min}$ on ice. Next, the samples were washed twice with ice-cold PBS containing $2 \% \mathrm{FCS}$ and $0.1 \% \mathrm{NaN}_{3}$, followed by centrifugation $\left(300 \mathrm{x}\right.$ g for $5 \mathrm{~min}$ at $\left.4^{\circ} \mathrm{C}\right)$. The binding of $14 \mathrm{G} 2 \mathrm{a}$ mAb to the neuroblastoma cells was 
A

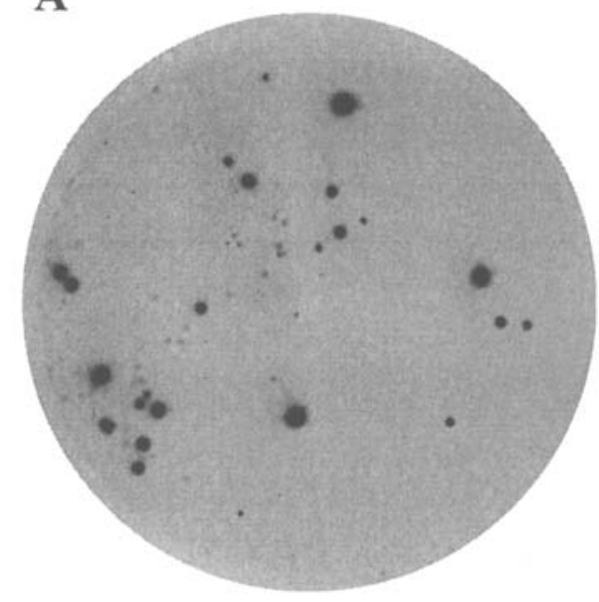

B

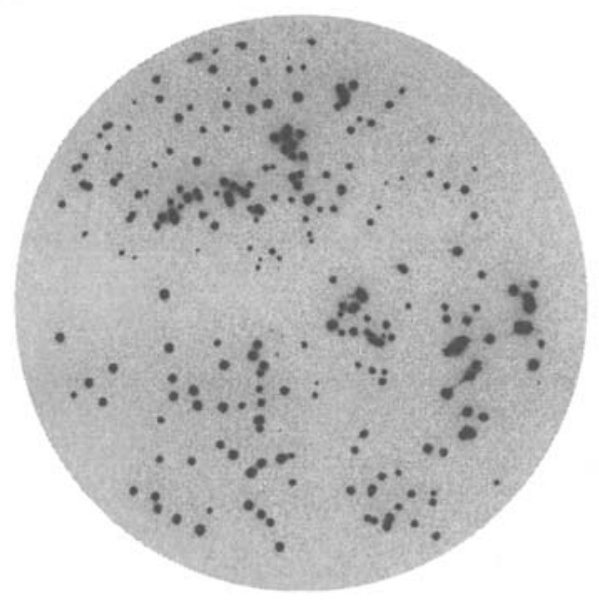

Figure 1. Results of immunoblotting experiments. (A) Replicas of bacteria infected with phage particles were prepared on nitrocellulose membranes, then incubated with the anti-GD2 ganglioside 14G2a mAb, and subsequently with the polyclonal HRP-conjugated anti-mouse Ig antibodies. The signal was developed with the ECL Plus detection reagent. The first series of immunoblotting experiments was performed to isolate the 14G2a binding phage clones from viral pools obtained after the panning experiments. (B) The second round of immunoblotting experiments was performed on the amplified phage clones to confirm their binding to $14 \mathrm{G} 2 \mathrm{a}$.

detected with the FITC-conjugated $\left(\mathrm{Fab}^{\prime}\right)_{2}$ fragments binding mouse $\mathrm{IgG}, \mathrm{IgM}$ and $\mathrm{IgA}$, dissolved 1:40 in PBS containing $2 \% \mathrm{FCS}$ and $0.1 \% \mathrm{NaN}_{3}\left(45 \mathrm{~min}, 4^{\circ} \mathrm{C}\right)$. After the washing step, the cells were analyzed using a flow cytometer (FACSScan, BD Biosciences, Erembodegen, Belgium). Based on the signal from negative controls (without 14G2a $\mathrm{mAb}$ ), the pools of cells that bound $14 \mathrm{G} 2 \mathrm{a}$ mAb were determined. The fluorescence signal in the samples (mean fluorescence intensity, MFI) was extracted from the data, and $\%$ of inhibition of binding of $14 \mathrm{G} 2 \mathrm{a}$ mAb to the IMR-32 cells by each phage clone was calculated using the formula $\%$ inhibition $=\left(1-\mathrm{MFI}_{\# \text { peptide }} / \mathrm{MFI}_{\max }\right) \times 100 \% . \mathrm{MFI}_{\# \text { peptide }}$ was the mean fluorescence intensity value of samples incubated with a given peptide-expressing phage clone, and $\mathrm{MFI}_{\max }$ was the mean fluorescence intensity value of samples incubated with the phage clone \#0. The measurements were performed in duplicate, and the experiments were repeated three times.

Synthetic peptides in dilutions ranging from $0.1-1000 \mu \mathrm{M}$ were incubated with $200 \mathrm{ng}$ of $14 \mathrm{G} 2 \mathrm{a}$ mAb in PBS containing $2 \% \mathrm{BSA}\left(\mathrm{O} / \mathrm{N}, 4^{\circ} \mathrm{C}\right)$, then used in a competition assay on IMR-32 neuroblastoma cells, and analyzed using flow cytometry technique (as described above). A sample with non-binding peptide \#Con (HEDIISLWDQSLK), a peptide from HIV-1 envelope protein was included as a specificity control (31). Based on the signal from negative controls (without 14G2a mAb), the pools of cells that bound the $14 \mathrm{G} 2 \mathrm{a} \mathrm{mAb}$ were determined. The fluorescence signal in the samples (MFI) was extracted from the data, and \% of inhibition of binding of $14 \mathrm{G} 2 \mathrm{a}$ mAb to the IMR-32 cells by each synthetic peptide was calculated using the formula $\%$ inhibition $=\left(1-\mathrm{MFI}_{\# \text { peptide }} / \mathrm{MFI}_{\max }\right) \times 100 \% \cdot \mathrm{MFI}_{\# \text { peptide }}$ was the mean fluorescence intensity value of samples incubated with a given concentration of the synthetic peptide tested, and $\mathrm{MFI}_{\max }$ was the mean fluorescence intensity value of samples incubated with $14 \mathrm{G} 2 \mathrm{a}$ mAb alone. The $\mathrm{IC}_{50}$ was defined as the concentration of the given peptide that reduced the binding of $14 \mathrm{G} 2 \mathrm{a}$ mAb to IMR-32 cells by $50 \%$. The mean $\mathrm{IC}_{50}$ value was calculated based on the results from three independent experiments.

\section{Results}

Isolation of phage-displayed peptides binding the anti-GD2 ganglioside antibody 14G2a. We performed biopanning experiments of the LX-8 phage display peptide library, encoding constrained 12 aa peptides, using the anti-GD2 ganglioside mouse monoclonal antibody 14G2a. Two types of panning experiments were designed. One was carried out as a 4-round 'in-solution' biopanning, in which the phagedisplayed peptide library was incubated with 30-, 10-, 3and 1-nM concentrations of the screening antibodies for the first 3 rounds, and the 3- and 1-nM 14G2a mAb during the final round. The second experiment was performed as a 'solid phase' biopanning experiment (6 rounds) in microplate wells coated with the 100-nM biotinylated-screening molecule immobilized via streptavidin. Both protocols resulted in isolation and amplification of pools of phages enriched for 14G2a binders, as verified by ELISA performed after each round (data not shown).

Immunoblotting, applied in the next step, allowed us to verify the presence of the $14 \mathrm{G} 2$ a binding phages in the pools generated after both types of panning. Replicas of bacteria infected with the phages on nitrocellulose membranes were screened with $14 \mathrm{G} 2 \mathrm{a}$ mAb. Then, the binding of the antibody was detected with the secondary HRP-conjugated antibodies, and the membranes were developed with electrochemiluminescence technique. The experiments confirmed that the phage pools obtained from the biopanning experiments were indeed enriched in the 14G2a-binding clones. Furthermore, analyses of the results led to the identification of numerous phage-infected bacterial colonies, whose replicas yielded a strong signal from the binding of 14G2a mAb (Fig. 1A). We chose 60 colonies that were subsequently re-screened in the 
Table I. The phage clones isolated with immunoblotting and their binding reactivity to $14 \mathrm{G} 2 \mathrm{a}$ mAb as determined with ELISA.

\begin{tabular}{|c|c|c|c|c|c|}
\hline Phage clone & $\begin{array}{l}\text { Fold rise of } \\
\text { ELISA value }^{\mathrm{a}}\end{array}$ & Phage clone & $\begin{array}{c}\text { Fold rise of } \\
\text { ELISA value }^{\mathrm{a}}\end{array}$ & Phage clone & $\begin{array}{l}\text { Fold rise of } \\
\text { ELISA value }^{\mathrm{a}}\end{array}$ \\
\hline $1-b$ & 1.90 & $25-a$ & 4.90 & $85-c t$ & 17.70 \\
\hline $2-b$ & 1.80 & $26-c$ & 5.00 & 86-ct & 11.45 \\
\hline $3-\mathrm{a}$ & 5.60 & $27-c$ & 1.20 & 94-at & 3.90 \\
\hline $4-\mathrm{a}$ & 4.30 & $28-e$ & 1.20 & B-2 & 13.40 \\
\hline $5-a$ & 1.20 & $2-b t$ & 2.30 & B-4 & 8.40 \\
\hline $6-a$ & 0.90 & 4-bt & 5.20 & $\mathrm{~F}-1$ & 12.60 \\
\hline $7-c$ & 4.00 & $6-b t$ & 2.10 & F-2 & 12.10 \\
\hline $8-a$ & 1.10 & 8 -bt & 11.20 & $\mathrm{~F}-4$ & 13.00 \\
\hline $9-c$ & 1.70 & 15 -at & 3.20 & $\mathrm{~F}-5^{\prime}$ & 14.20 \\
\hline $10-\mathrm{a}$ & 7.90 & 19 -at & 5.20 & F-5" & 14.70 \\
\hline $12-\mathrm{c}$ & 4.90 & 22 -at & 5.40 & G-1 & 9.60 \\
\hline $17-\mathrm{a}$ & 4.10 & 24-at & 1.60 & G-2 & 22.70 \\
\hline $18-\mathrm{b}$ & 4.40 & $25-b t$ & 3.70 & G-3 & 15.70 \\
\hline $19-b$ & 2.00 & $52-\mathrm{ct}$ & 3.40 & $\mathrm{H}-1$ & 14.30 \\
\hline $20-\mathrm{a}$ & 1.70 & $55-b t$ & 1.10 & $\mathrm{H}-2$ & 17.00 \\
\hline $21-c$ & 4.40 & $56-b t$ & 3.90 & $\mathrm{H}-3$ & 18.40 \\
\hline $22-b$ & 3.70 & 59-at & 1.70 & $\mathrm{H}-4$ & 16.40 \\
\hline $23-c$ & 1.70 & $65-b t$ & 4.50 & & \\
\hline $24-b$ & 4.00 & 75 -at & 17.00 & & \\
\hline
\end{tabular}

${ }^{a}$ For ELISA the isolated and amplified phage clones were captured via their displayed peptides by the biotinylated 14G2a mAb immobilized to streptavidin, and then were detected with the HRP-conjugated anti-phage pVIII antibody. Each value was a ratio of the mean values of OD 450-nm readings of the respective phage clone and the phage clone \#0.

Table II. The sequences of the 12 aa peptides isolated from the LX-8 phage-displayed peptide library through biopanning with $14 \mathrm{G} 2 \mathrm{a}$ mAb.

\begin{tabular}{llc}
\hline Peptide & Identified sequence & Number of clones \\
\hline$\# 8$ & NCDLLTGPMLCV & 12 \\
$\# 65$ & SCQSTRMDPNCW & 3 \\
$\# 85$ & VCNPLTGALLCS & 6 \\
$\# 94$ & RCNPNMEPPRCF & 4 \\
$\# D$ & GCDALSGHLLCS & 14 \\
\hline
\end{tabular}

Total number of sequenced clones

39

second round of immunoblotting (Fig. 1B). Fifty-five of the phage clones again yielded a strong positive signal of $14 \mathrm{G} 2 \mathrm{a}$ $\mathrm{mAb}$ binding, as compared to a randomly chosen phage clone $\# 0$. The phage $\# 0$ was picked in the first round of immunoblotting and used as a specificity control since it did not exhibit binding to the antibody (data not shown).

Determination of the phage-displayed peptide sequences. To further characterize and determine the relative affinity of the isolated phage clones to the GD2-specific antibody, we performed ELISA on all of the 55 isolated clones. Amplified and PEG-purified viral particles $\left(10^{10}\right)$ were captured via their displayed peptides by the biotinylated $14 \mathrm{G} 2 \mathrm{a} \mathrm{mAb}$ immobilized in microplate wells to streptavidin, and then detected with the HRP-conjugated anti-phage pVIII antibody (Table I). In comparison to phage \#0, among all the screened clones, 39 exhibited a signal that was $\sim 2$-fold higher. All these phage clones were scored as specific binders to the 14G2a. The phage clones that yielded signals which were insignificant compared to the control phage \#0, were removed from further analyses (16 clones). Based on the results of the ELISAs, all 39 phage clones were selected for DNA sequencing. Analysis of the sequencing data yielded 5 different 12 aa peptide sequences, which were collected in Table II. All of the identified sequences have cysteine residues at positions 2 and 11. Analysis of the sequence of the \#0 phage revealed a stop codon at the first position in the peptide encoding sequence, suggesting that the phage \#0 expressed no peptide on the coat surface.

Analysis of the sequence similarities among the isolated peptides was used to estimate the relative contribution of different amino acids of non-sibling peptides to their binding ability to $14 \mathrm{G} 2 \mathrm{a}$ mAb. Alignment of the sequences allowed for indication of the degree of identity between the verified sequences. One group of peptides is represented by sequences \#8, \#85 and \#D. A motif of 3 aa residues Leu-ThrGly were found in peptides \#8 and \#85, while \#D contained Ser in place of Thr. In addition, the peptides \#85 and \#D 


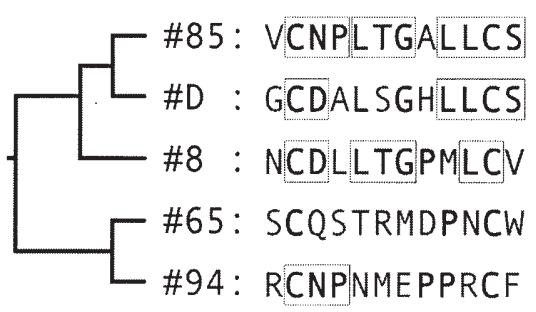

Figure 2. Dendrogram of five peptide sequences identified as GD2 mimics. Sequence analysis was performed with the ClustalW multiple sequence alignment program with amino acid identity matrix. The analysis revealed two clusters: (\#85, \#D, \#8) and (\#65, \#94). Identical positions in the sequence are printed in bold type. Motifs of sequence similarity have been identified and highlighted.

contained motif Leu-Leu-Cys-Ser. Peptide \#8 contained Leu in position 10. Moreover, both \#8 and \#D contained Asp in the third position. Peptide \#65 and \#94 represented the second group, which substantially differed in sequence compared to the peptides \#8, \#85 and \#D. Both \#65 and \#94 peptides lacked the Leu-Thr/Ser-Gly motif and the terminally located Leu residues. These two peptides were characterized by the presence of Pro at position 9. Cys-Asn-Pro motif was also present in the \#85 and \#94 sequences, and Pro was present in position 8 in peptides \#8 and \#94 (Fig. 2).

The role of displayed peptide disulfide bonds in the binding to $14 G 2 a m A b$. In the following experiments, we aimed to determine the role of the peptide secondary structure, stabilized by the disulfide bonds formed between the cysteine residues at positions 2 and 11, in the binding of the phagedisplayed peptides to the anti-GD2 antibody. Therefore, the phage clones representing all identified sequences were treated with dithiothreitol (DDT), and N-ethylomaleimide (NEM), which modify the peptides. DTT was used to reduce disulfide bonds, while NEM was used to prevent the reforming of these bonds, since it blocks cysteine through reaction with sulphydryl residues. The immobilized phage clones $\left(0.7 \times 10^{11} \mathrm{ph}\right)$ were subjected to DDT and NEM treatment alone or in combinations $\left(\mathrm{DDT}^{+} / \mathrm{NEM}^{-}, \mathrm{DDT}^{+} / \mathrm{NEM}^{+}, \mathrm{DDT}^{-} / \mathrm{NEM}^{+}\right.$or $\mathrm{DDT}^{-} / \mathrm{NEM}^{-}$). Subsequently, the phages were incubated with 14G2a mAb, and binding to the antibody was detected with the HRP-conjugated anti-mouse Ig antibodies, and developed with the TMB substrate. As shown in Fig. 3, we observed a significant decrease in affinities of all the isolated peptides to 14G2a mAb in cysteine modifying conditions (the presented data were normalized to the signal obtained for the phage clone \#0). Changes were seen for the wells coated with the phage clones expressing all 5 identified sequences, which were treated with DTT alone, as well as DTT and NEM. No such changes in the binding of the $14 \mathrm{G} 2 \mathrm{a}$ mAb were measured for the non-treated phage-coated wells as well as the wells treated only with NEM. Specificity controls were included to ensure that the observed effects were indeed due to modifications of the secondary structure of the peptides stabilized with the disulphide bond. Additional wells were coated with non-constrained 15 aa GD2 ganglioside mimicking peptide \#47, and subjected to ELISA in reducing conditions, as above. No changes in the 14G2a binding signal

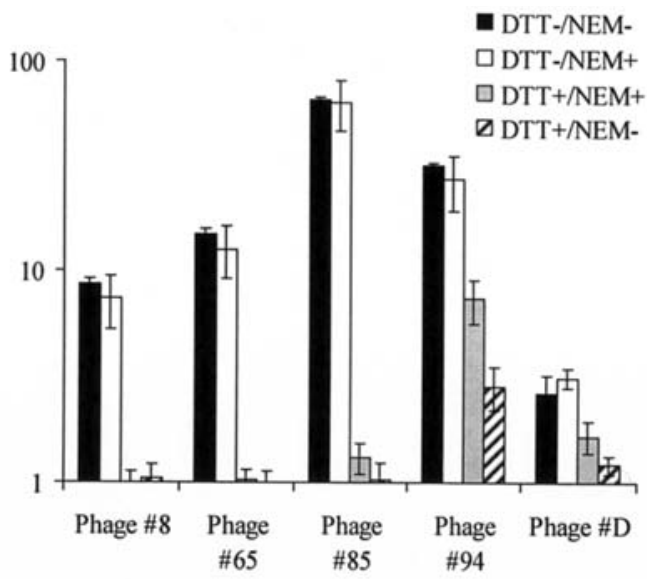

Figure 3. Phage ELISA under reducing conditions. Immobilized phage clones representing 5 different peptide sequences (phage \#8, \#65, \#85, \#94 and \#D) isolated from the LX-8 peptide library were subjected to reducing conditions (with dithithreitol, $\mathrm{DDT}^{+} / \mathrm{NEM}^{-}$), cysteine-blocking conditions (with $\mathrm{N}$-ethylmaleimide, DTT- $/ \mathrm{NEM}^{+}$) or both $\left(\mathrm{DTT}^{+} / \mathrm{NEM}^{+}\right)$. A control without the cysteine modifying compounds was also included (DTT-/NEM ${ }^{-}$). Subsequently, the phages were incubated with $14 \mathrm{G} 2 \mathrm{a}$ mAb, and the antiGD2 antibody binding was detected with the HRP-conjugated anti-mouse Ig antibodies. The presented values were normalized to data obtained for the non-binding phage $\# 0$. Each value is a mean \pm SE from duplicate experiments. Data shown are representative of three individual experiments.

were detected in these wells (data not shown). The obtained results confirm that the effect of the reduction of the binding of $14 \mathrm{G} 2 \mathrm{a} \mathrm{mAb}$ to the phage clones representing all 5 identified sequences was due to DTT- and NEM-induced changes in the secondary structure of the peptides. To conclude, the experiments showed that the disulfide bond is necessary for the anti-GD2 antibody to bind to the phage particles expressing the identified peptides.

The phage-expressed peptides compete with IMR-32 neuroblastoma cells for binding of the anti-GD2 14G2a mAb. To further characterize the phenomenon of mimicry of the phage-expressed peptides to GD2 ganglioside, we performed a competition assay on a human neuroblastoma cell line IMR-32, which abundantly expresses GD2 ganglioside. 14G2a mAb (200 ng) was incubated overnight with $10^{12}$ ph of the clones expressing the identified peptides, and then was used to stain the GD2 ganglioside present on the IMR-32 cells. The binding of the antibody to the cells was detected with the FITC-conjugated secondary antibodies, and was analyzed with flow cytometry technique.

Inhibition of binding of $14 \mathrm{G} 2 \mathrm{a} \mathrm{mAb}$ to the GD2 ganglioside expressing neuroblastoma IMR-32 cells was observed for all of the phage clones screened (Fig. 4). The competition of the peptide-expressing phage clones for $14 \mathrm{G} 2 \mathrm{a}$ mAb resulted in a significant decrease in both the number of positively stained cells, as well as the mean fluorescence intensity values, compared to positive control samples, i.e. cells incubated with the $14 \mathrm{G} 2 \mathrm{a}$ mAb. Moreover, pre-incubation of the phage clone \#0 with the anti-GD2 ganglioside $\mathrm{mAb}$ had no effect on the binding of the antibody to IMR-32 cells. The above findings suggest that the observed decrease of the binding of the $14 \mathrm{G} 2 \mathrm{a}$ mAb to the GD2 ganglioside present on the cell surface of IMR-32 cells 

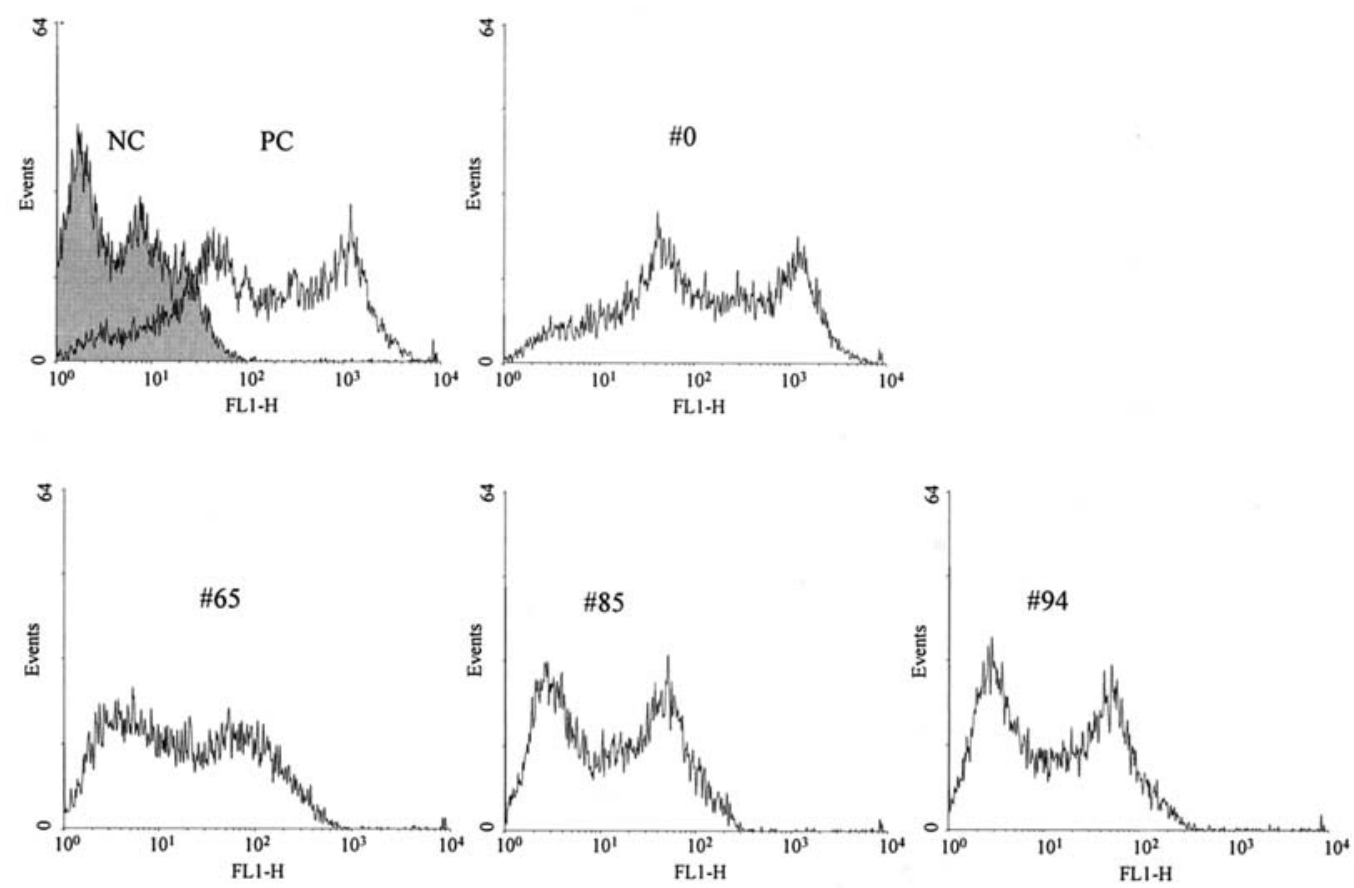

Figure 4. Results of competition test. Phage particles $\left(10^{12}\right)$ expressing the 5 different peptides binding to $14 \mathrm{G} 2 \mathrm{a}$ mAb were incubated overnight with $200 \mathrm{ng}$ of the antibody, and then were used in a competition assay on the GD2 ganglioside-positive IMR-32 neuroblastoma cells. The binding of 14G2a mAb to the cells was detected with the secondary FITC-conjugated $\left(\mathrm{Fab}^{\prime}\right)_{2}$ fragments using flow cytometry technique. Three peptides that exhibited the highest inhibition; the non-binding phage \#0; PC, positive control (no phage present); and NC, negative control (without 14G2a mAb) are shown. Data shown are a representative of three individual experiments.
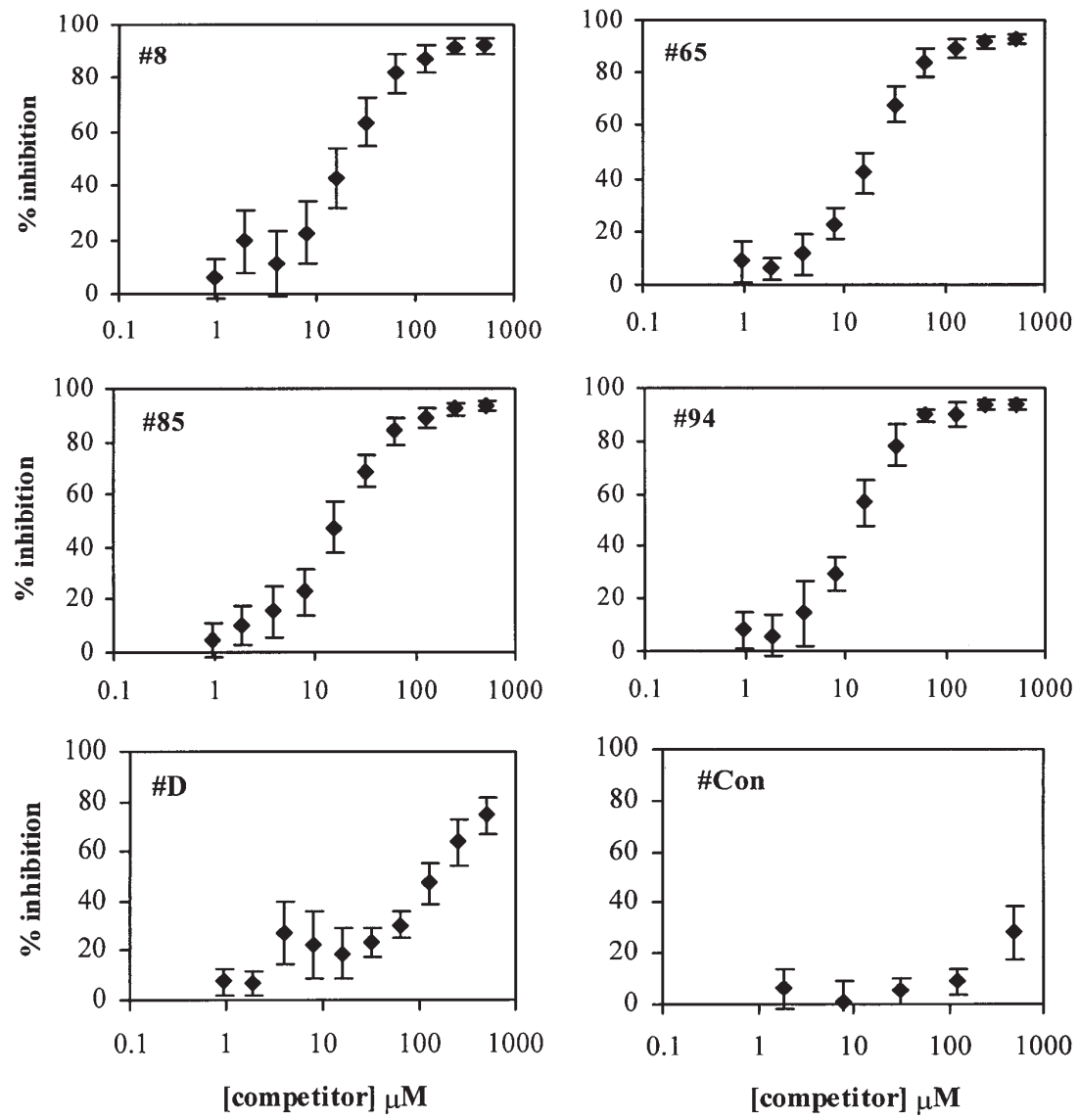

Figure 5. The binding of the synthetic peptides to $14 \mathrm{G} 2 \mathrm{a}$ mAb was verified using the competition assay. The synthetic peptides (\#8, \#65, \#85, \#94 and \#D) were incubated overnight with $200 \mathrm{ng}$ of the $14 \mathrm{G} 2 \mathrm{a} \mathrm{mAb}$, and then used in the competition assay on the IMR-32 cells. The binding of 14G2a mAb was detected with the secondary FITC-conjugated antibodies using flow cytometry. A sample with a non-binding peptide was included as a specificity control (\#Con peptide). Data shown represent means $\pm \mathrm{SE}$ from three independent experiments. 
was due to the presence of phage-displayed peptides. Based on the signal from negative controls, the pools of IMR-32 cells that specifically bound the $14 \mathrm{G} 2 \mathrm{a}$ mAb were determined. In these pools, mean fluorescence intensity was measured, and then used for the calculation of $\%$ of inhibition. Among the 5 phage clones tested, the phages expressing peptides \#65, \#85 and 94\# showed the highest $\%$ of inhibition; $76.8 \%( \pm 5.1)$ for the phage \#65; 82.9\% ( \pm 4.1$)$ for the phage \#85; and $82.9 \%( \pm 1.1$ ) for the phage \#94 (Fig. 4). The values calculated for the last 2 tested phages were significantly lower; $30.6 \%( \pm 7.4)$ and $45.9 \%( \pm 4.8)$, for the phages \#8, and \#D, respectively (data not shown).

Synthetic peptides are mimics of GD2 ganglioside. Based on the results of the above experiments, synthetic peptides encoding the 5 identified sequences were tested in the competition assay on IMR-32 cells. This test allowed us to verify the results observed with phage-displayed peptides. The concentrations of the peptides that were used ranged from 0.1-1000 $\mu \mathrm{M}$. Indeed, all the synthetic peptides prevented the $14 \mathrm{G} 2 \mathrm{a}$ mAb from binding to IMR-32 cells. The observed effects were dose dependent. A sample with a non-binding peptide was included as a specificity control (\#Con peptide). For this peptide, only slight inhibition was observed for concentrations of the peptide $>100 \mu \mathrm{M}$. The results suggest that the observed effects of inhibition of binding of the anti-GD2 mAb to IMR-32 cells were specific for the synthetic peptides isolated from the LX-8 library (Fig. 5). $\mathrm{IC}_{50}$ values were calculated for the GD2-mimicking peptides. All 4 peptides isolated with the 'in solution' panning protocol had comparable equal abilities to compete for the binding site of the $14 \mathrm{G} 2 \mathrm{a}$ mAb with the GD2 ganglioside expressed on IMR-32 cells. The $\mathrm{IC}_{50}$ values for these peptides were: $14.0 \pm 2.9 \mu \mathrm{M}$ for peptide $\# 94,17.8 \pm 5.1 \mu \mathrm{M}$ for peptide \#85, 20.3 $\pm 4.2 \mu \mathrm{M}$ for peptide \#65 and $20.4 \pm 6.8 \mu \mathrm{M}$ for peptide \#8. The $\mathrm{IC}_{50}$ value determined for peptide \#D was $\sim 8$ times higher $(165.8 \pm 60.2 \mu \mathrm{M})$. To conclude, we state that all of the identified synthetic peptides were mimics of GD2 ganglioside, since they were shown to specifically compete for the binding of $14 \mathrm{G} 2 \mathrm{a}$ mAb with its native antigen, the GD2 ganglioside present on IMR-32 neuroblastoma cells.

\section{Discussion}

In the current study, we focused our research to isolate constrained peptides from phage-displayed peptide library LX-8 with 14G2a mAb, and to characterize their ability to mimic GD2 ganglioside, which is one of the most prominent neuroblastoma antigens. The performed biopanning experiments led to the isolation of affinity-enriched phage pools for the screening molecule. Two rounds of immunoblotting were successfully applied to eliminate irrelevant binders that represented e.g. plastic, BSA as well as Fc binding clones as such phage clones could have been amplified, despite the pre-adsorption step preceding each panning round. Additionally, prior to the decoding of the peptide sequences from the viral ssDNA, application of ELISA allowed us to estimate the strength of 14G2a binding of all 55 clones isolated through plaque assay, and to discriminate between weak and strong binders. As a result,
16 weak binding clones were excluded from further analyses. Five varying peptide sequences were identified through analyses of the sequencing data. As the identified peptide sequences were isolated from phage pools obtained through panning carried out according to two protocols, and with different $14 \mathrm{G} 2 \mathrm{a}$ mAb concentrations, it was impossible to establish a correlation between the measured 14G2a binding strength and the frequency of the isolated clones. Such a correlation has been reported in some experiments, while other data have suggested only a weak link between the binding affinity of the phage clone and its selection frequency $(32,33)$. The fact that only one sequence (\#D) was identified with the 6-round 'solid phase' protocol may be explained by the overgrowth of certain clones caused by factors other than affinity (e.g. biological fitness).

Analysis of the sequence similarities between the isolated peptide sequences was used to estimate the relative binding contributions to a receptor of different amino acids of nonsibling peptides (34). However, since only 5 peptide sequences were identified among 39 sequenced clones, such detailed analysis cannot be performed. Yet, our isolated peptides showed some sequence identities. The presence of the defined motif Leu-Thr/Ser-Gly did not seem to be crucial for binding to $14 \mathrm{G} 2 \mathrm{a}$ mAb, as peptides \#65 and \#94 lacked the motif as well as Leu at position 9, compared to peptides \#8, \#85 and \#D. Yet, similar 14G2a binding affinities were obtained for the peptides \#65, \#85 and \#94, both presented on the phage surface as well as in the synthetic form. Notably, the secondary structure of the peptides, stabilized by the disulfide bridging between cysteine residues at positions 2 and 11, was shown pivotal for the 14G2a binding abilities of all isolated peptides. Thus, it may be that the observed mimicry of the GD2 ganglioside by the peptides was related both to the presence of the specific amino acids and the overall conformation of the peptides stabilized with disulphide bridge. More information on the involvement of the specific amino acid residues in the binding of the peptides to the GD2-specific antibody may be gained from replacement and truncation experiments. Additionally, such analyses would allow further optimization of the obtained sequences (35). Other peptide mimicking GD2 gangliosides have already been published. In comparison, our 5 peptides are of different length, have no considerable sequence identity, and have no obvious similarities in motif. Linear 15 aa peptides were isolated with $14 \mathrm{G} 2 \mathrm{a}$ mAb (29). Forster-Waldl and coresearchers reported phage clones expressing cyclic peptides build by 10 amino acids, which were looped by the addition of 2 flanking cysteine residues, and were isolated from the phage-displayed library based on pIII fusions, and with the anti-GD2 ganglioside antibody ch14.18. However, the exact role of the disulphide bridge has not been investigated for their peptides (36).

The therapeutic potential of peptides derived from phagedisplayed peptide libraries relies on the fact that they can structurally mimic the native antigen interactions with the antigen-binding site of the screening antibody. The final proof that all of the isolated phage-displayed peptides interacted with the GD2 ganglioside-binding site of the 14G2a mAb was obtained from competition assays. Here, we measured quantitative differences in the inhibition of the 
binding of $14 \mathrm{G} 2 \mathrm{a}$ mAb to its native antigen, GD2 ganglioside, expressed on IMR-32 neuroblastoma cells. With reference to the calculated percentage of inhibition, the phage clones displaying peptides \#94, \#65 and \#85 were shown to almost completely inhibit the binding of the $14 \mathrm{G} 2 \mathrm{a}$ mAb to the GD2-positive neuroblastoma cells. The phage clones representing peptides \#8 and \#D performed, respectively, three and two times less efficiently in the inhibition assay. As the phage clone $\# 0$, which expresses no peptide, yielded no inhibition, we concluded that the observed effects were specific due to the presence of the displayed peptides. Moreover, we confirmed specific interactions of 14G2a mAb binding with the antigen-binding site during the inhibition tests carried out with chemically synthesized peptides. Based on the results of the inhibition of binding of $14 \mathrm{G} 2 \mathrm{a}$ to IMR32 cells by synthetic peptides, we concluded that all five peptides transferred to the non-phage milieu were still mimicking GD2 ganglioside. Peptides \#8, \#65, \#85 and \#94 isolated with the 'in solution' panning protocol showed similar $\mathrm{IC}_{50}$ values, while peptide \#D showed significantly higher $\mathrm{IC}_{50}$ values. The reasons for this were not investigated. We hypothesized that analysis of the peptides in a monovalent system overcame the affinities of multiply displayed peptides and effects of the phage on the peptide structure, as it might occur on the phage surface.

The mimicry of peptides isolated from phage libraries can be evaluated on various levels. These include a structural mimicry related to the $3 \mathrm{D}$ conformation, an immunochemical mimicry based on the patterns of binding to an antibody, and a functional mimicry that allows induction of immune responses specific for a nominal antigen (37). Based on the available research data it is apparent that these levels may not necessarily be interrelated. For instance, Willers and colleagues found that peptide mimics of GD3 ganglioside did not elicit any detectable immune responses in mice, probably due to the presence of common motifs between the reported GD3 mimics, and mouse or human proteins (38). On the contrary, peptide mimics of Lewis $\mathrm{Y}$ induced specific anticarbohydrate antibodies in mice (39). Furthermore, the generated immune responses could be further manipulated with various delivery schedules, i.e. prime/boost strategies with peptides and carbohydrate, or a DNA vaccination approach $(21,40)$. The presence of anti-GD2 ganglioside responses has already been investigated with application of mimicking peptides $(29,41)$. Indeed, mutual relationships between the observed mimicry in binding to $14 \mathrm{G} 2 \mathrm{a}$ mAb and the functional ability to induce GD2 ganglioside-specific immune responses must be established if the GD2 mimicking peptides isolated from the LX-8 library are to be evaluated as components of anti-tumor vaccines. Further research on animal models has been planned to establish the ability of our novel mimics of GD2 ganglioside to overcome the undesired low immunogenicity of the ganglioside. Since our peptides do not show sequence similarities to the other reported GD2 mimotopes, it is of great interest to establish whether they could induce immune responses, and to qualitatively and quantitatively analyze the response. Possibly, our mimics could be used in the form of a multiepitope vaccine to further broaden or augment the observed anti-GD2 ganglioside responses.
Application of peptide mimotopes of the GD2 ganglioside is one of the currently developed strategies to overcome poor immunogenicity of GD2 ganglioside, and to induce therapeutically significant anti-tumor immune responses which could supplement standard treatment protocols of malignancies such as neuroblastoma or melanoma. The novel protocols of active immunization include vaccination with conjugates of carbohydrate antigens with protein carriers. In clinical trials vaccines based on GD2 and GM2 gangliosides conjugated with KLH with QS-21 have been evaluated in patients with melanoma (42). GD2 ganglioside mimicking anti-idiotypes are another clinically advanced alternative. Foon and colleagues have reported induction of anti-GD2 ganglioside humoral responses, predominantly IgG antibodies, in a cohort of 47 patients with advanced melanoma immunized with TriGem, the mouse monoclonal antiidiotype antibody (Ab2) mixed with the QS-21 adjuvant (43). Recently, a human anti-idiotype Fab fragment (GK8) was cloned from a neuroblastoma patient treated with ch14.18. The antibody fragment inhibited the binding of ch14.18 to the GD2 ganglioside similar to the patient's serum. Additionally, the fragment was shown to induce Ab3 against the original target in rabbits, and therefore may be a suitable tumor vaccine candidate (44). Finally, the fact that induction of anti-GD2 antibody responses in children with advanced neuroblastoma, which were treated at the remission time with 3F8 mAb, was associated with long-term survival strengthens the need to further develop vaccination protocols based on surrogate antigens of the GD2 ganglioside (45).

In conclusion, the above results confirmed that our constrained peptides isolated from the LX-8 phage-displayed peptide library with $14 \mathrm{G} 2 \mathrm{a}$ mAb are mimics of the tumorassociated GD2 ganglioside. These results warrant further consideration and study of the molecules as possible novel immunogens to overcome tolerance to the GD2 ganglioside, and to induce specific immune responses that may be clinically important for the treatment of patients bearing GD2 expressing tumors, especially, to control the minimal residual disease.

\section{Acknowledgements}

This study was supported by grant no. 3P05A 00124 from the Polish Ministry of Scientific Research and Information Technology. We are grateful to Dr Ralph A. Reisfeld for the 14G2a-producing hybridoma cells. We thank Dr Malgorzata Bzowska for help with the flow cytometry analysis.

\section{References}

1. Varki A: Glycosylation changes in cancer. In: Essentials of Glycobiology. Varki A, Cummings R, Esko R, Freeze H, Hart G and Marth J (ed). Cold Spring Harbor Laboratory Press, New York, pp537-549, 1999.

2. Livingston PO, Zhang S and Lloyd KO: Carbohydrate vaccines that induce antibodies against cancer. 1. Rationale. Cancer Immunol Immunother 45: 1-9, 1997.

3. Birkle S, Zeng G, Gao L, Yu RK and Aubry J: Role of tumorassociated gangliosides in cancer progression. Biochimie 85: 455-463, 2003.

4. Hettmer S, Malott C, Woods W, Ladisch S and Kaucic K: Biological stratification of human neuroblastoma by complex "B" pathway ganglioside expression. Cancer Res 63: 7270-7276, 2003.

5. Hettmer S, McCarter R, Ladisch S and Kaucic K: Alterations in neuroblastoma ganglioside synthesis by induction of GD1b synthase by retinoic acid. Br J Cancer 91: 389-397, 2004. 
6. Valentino L, Moss T, Olson E, Wang HJ, Elashoff R and Ladisch S: Shed tumor gangliosides and progression of human neuroblastoma. Blood 75: 1564-1567, 1990.

7. Ruan S, Raj BK and Lloyd KO: Relationship of glycosyltransferases and mRNA levels to ganglioside expression in neuroblastoma and melanoma cells. J Neurochem 72: 514-521, 1999.

8. Yoshida S, Fukumoto S, Kawaguchi H, Sato S, Ueda R and Furukawa K: Ganglioside G(D2) in small cell lung cancer cell lines: enhancement of cell proliferation and mediation of apoptosis. Cancer Res 61: 4244-4252, 2001.

9. Shurin GV, Shurin MR, Bykovskaia S, Shogan J, Lotze MT and Barksdale EM Jr: Neuroblastoma-derived gangliosides inhibit dendritic cell generation and function. Cancer Res 61: 363-369, 2001.

10. Ravindranath MH and Morton DL: Antigens: carbohydrates. In: Encyclopedia of life sciences. Nature Publishing Group. www.els.net, 2001.

11. Wu ZL, Schwartz E, Seeger R and Ladisch S: Expression of GD2 ganglioside by untreated primary human neuroblastomas. Cancer Res 46: 440-443, 1986.

12. Reuland P, Geiger L, Thelen MH, Handgretinger R, Haase B, Muller-Schauenburg W, Niethammer D and Bares R: Follow-up in neuroblastoma: comparison of metaiodobenzylguanidine and a chimeric anti-GD2 antibody for detection of tumor relapse and therapy response. J Pediatr Hematol Oncol 23: 437-442, 2001.

13. Beiske K, Ambros PF, Burchill SA, Cheung IY and Swerts K: Detecting minimal residual disease in neuroblastoma patients the present state of the art. Cancer Lett 228: 229-240, 2005.

14. Kramer K, Gerald WL, Kushner BH, Larson SM, Hameed M and Cheung NK: Disaloganglioside GD2 loss following monoclonal antibody therapy is rare in neuroblastoma. Med Pediatr Oncol 36: 194-196, 2001.

15. Cheung NK, Kushner BH and Kramer K: Monoclonal antibodybased therapy of neuroblastoma. Hematol Oncol Clin North Am 15: 853-866, 2001.

16. Fredman P, Hedberg K and Brezicka T: Gangliosides as therapeutic targets for cancer. BioDrugs 17: 155-167, 2003.

17. Smith GP and Petrenko VA: Phage display. Chem Rev 97: 391-410, 1997.

18. Ashok BT, David L, Chen YG, Garikapaty VP, Chander B, Kanduc D, Mittelman A and Tiwari RK: Peptide mimotopes of oncoproteins as therapeutic agents in breast cancer. Int $\mathrm{J}$ Mol Med 11: 465-471, 2003.

19. Zhang H, Zhong Z and Pirofski LA: Peptide epitopes recognized by a human anti-cryptococcal glucuronoxylomannan antibody. Infect Immun 65: 1158-1164, 1997.

20. Fleuridor R, Lees A and Pirofski LA: A cryptococcal capsular polysaccharide mimotope prolongs the survival of mice with Cryptococcus neoformans infection. J Immunol 166: 1087-1096, 2001.

21. Kieber-Emmons T, Monzavi-Karbassi B, Wang B, Luo P and Weiner DB: Cutting edge: DNA immunization with minigenes of carbohydrate mimotopes induce functional anti-carbohydrate antibody response. J Immunol 165: 623-627, 2000.

22. Bonnycastle LL, Mehroke JS, Rashed M, Gong X and Scott JK: Probing the basis of antibody reactivity with a panel of constrained peptide libraries displayed by filamentous phage. J Mol Biol 258: 747-762, 1996.

23. Way JC, Davis MA, Morisato D, Roberts DE and Kleckner N: New Tn10 derivatives for transposon mutagenesis and for construction of lacZ operon fusions by transposition. Gene 32: 369-379, 1984.

24. Murray JL, Cunningham JE, Brewer H, Mujoo K, Zukiwski AA, Podoloff DA, Kasi LP, Bhadkamkar V, Fritsche HA and Benjamin RS: Phase I trial of murine monoclonal antibody $14 \mathrm{G} 2 \mathrm{a}$ administered by prolonged intravenous infusion in patients with neuroectodermal tumors. J Clin Oncol 12: 184-193, 1994.

25. Mendez A, Bonnycastle LL, Pan OC and Scott JK: Screening peptide libraries. In: Phage display. A laboratory manual. Barbas CF, Burton DR, Scott JK and Silverman GJ (eds). Cold Spring Harbor Laboratory Press, New York, pp17.8-17.11, 2001.

26. Tumilowicz JJ, Nichols WW, Cholon JJ and Greene AE: Definition of a continuous human cell line derived from neuroblastoma. Cancer Res 30: 2110-2118, 1970.

27. Hettmer S, Ladisch S and Kaucic K: Low complex ganglioside expression characterizes human neuroblastoma cell lines. Cancer Lett 225: 141-149, 2005.

28. Bonnycastle LL, Mendez A and Scott JK: General phage methods. In: Phage display. A laboratory manual. Barbas CF, Burton DR, Scott JK and Silverman GJ (eds). Cold Spring Harbor Laboratory Press, New York, pp15.5-15.17, 2001.

29. Bolesta E, Kowalczyk A, Wierzbicki A, Rotkiewicz P, Bambach B, Tsao CY, Horwacik I, Kolinski A, Rokita H, Brecher M, Wang X, Ferrone S and Kozbor D: DNA vaccine expressing the mimotope of GD2 ganglioside induces protective GD2 cross-reactive antibody responses. Cancer Res 65: 3410-3418, 2005.

30. Chenna R, Sugawara H, Koike T, Lopez R, Gibson TJ, Higgins DG and Thompson JD: Multiple sequence alignment with the Clustal series of programs. Nucleic Acids Res 31: 3497-3500, 2003.

31. Kropelin M, Susal C, Daniel V and Opelz G: Inhibition of HIV-1 rgp120 binding to $\mathrm{CD} 4+\mathrm{T}$ cells by monoclonal antibodies directed against the gp120 $\mathrm{C} 1$ or $\mathrm{C} 4$ region. Immunol Lett 63: 19-25, 1998

32. Balass M, Katchalski-Katzir E and Fuchs S: The alphabungarotoxin binding site on the nicotinic acetylcholine receptor: analysis using a phage-epitope library. Proc Natl Acad Sci USA 94: 6054-6058, 1997.

33. Sibille P and Strosberg AD: A FIV epitope defined by a phage peptide library screened with a monoclonal anti-FIV antibody. Immunol Lett 59: 133-137, 1997.

34. Valadon P, Nussbaum G, Boyd LF, Margulies DH and Scharff MD: Peptide libraries define the fine specificity of antipolysaccharide antibodies to Cryptococcus neoformans. J Mol Biol 261: 11-22, 1996.

35. Johnson DL, Farrell FX, Barbone FP, McMahon FJ, Tullai J, Hoey K, Livnah O, Wrighton NC, Middleton SA, Loughney DA, Stura EA, Dower WJ, Mulcahy LS, Wilson IA and Jolliffe LK: Identification of a 13 amino acid peptide mimetic of erythropoietin and description of amino acids critical for the mimetic activity of EMP1. Biochemistry 37: 3699-3710, 1998.

36. Forster-Waldl E, Riemer AB, Dehof AK, Neumann D, Bramswig K, Boltz-Nitulescu G, Pehamberger H, Zielinski CC, Scheiner O, Pollak A, Lode H and Jensen-Jarolim E: Isolation and structural analysis of peptide mimotopes for the disialoganglioside GD2, a neuroblastoma tumor antigen. Mol Immunol 42: 319-325, 2005.

37. Beninati $\mathrm{C}$ and Teti G: A meeting of mimics. Trends Microbiol 8: 492-493, 2000

38. Willers J, Lucchese A, Kanduc D and Ferrone S: Molecular mimicry of phage displayed peptides mimicking GD3 ganglioside. Peptides 20: 1021-1026, 1999.

39. Luo P, Agadjanyan M, Qiu J, Westerink MA, Steplewski MAJ and Kieber-Emmons T: Antigenic and immunological mimicry of peptide mimotopes of Lewis carbohydrate antigens. Mol Immunol 35: 865-879, 1998.

40. Monzavi-Karbassi B, Shamloo S, Kieber-Emmons M, Jousheghany F, Luo P, Lin KY, Cunto-Amesty G, Weiner DB and Kieber-Emmons T: Priming characteristic of peptide mimotopes of carbohydrate antigens. Vaccine 21: 753-760, 2003.

41. Riemer AB, Forster-Waldl E, Bramswig KH, Pollak A, Zielinski CC, Pehamberger H, Lode HN, Scheiner O and Jensen-Jarolim E: Induction of IgG antibodies against the GD2 carbohydrate tumor antigen by vaccination with peptide mimotopes. Eur J Immunol 36: 1267-1274, 2006.

42. Chapman PB, Morrisey D, Panageas KS, Williams L, Lewis JJ, Israel RJ, Hamilton WB and Livingston PO: Vaccination with a bivalent $G(M 2)$ and $G(D 2)$ ganglioside conjugate vaccine: a trial comparing doses of G(D2)-keyhole limpet hemocyanin. Clin Cancer Res 6: 4658-4662, 2000.

43. Foon KA, Lutzky J, Baral RN, Yannelli JR, Hutchins L, Teitelbaum A, Kashala OL, Das R, Garrison J, Reisfeld RA and Bhattacharya-Chatterjee M: Clinical and immune responses in advanced melanoma patients immunized with an anti-idiotype antibody mimicking disialoganglioside GD2. J Clin Oncol 118: 376-384, 2000.

44. Uttenreuther-Fischer MM, Kruger JA and Fischer P: Molecular characterization of the anti-idiotypic immune response of a relapse-free neuroblastoma patient following antibody therapy: a possible vaccine against tumors of neuroectodermal origin? (erratum in J Immunol 177: 2738, 2006) J Immunol 176: 7775 7786, 2006.

45. Cheung NK, Guo HF, Heller G and Cheung IY: Induction of Ab3 and Ab3' antibody was associated with long-term survival after anti-G(D2) antibody therapy of stage 4 neuroblastoma. Clin Cancer Res 6: 2653-2660, 2000. 